\title{
Demographic Trends and the Population Ageing: Why Matters?
}

\author{
*Tahmina Afrose \\ Department of Community Medicine, AIMST University, Malaysia
}

Submission: April 22, 2017; Published: April 24, 2017

*Corresponding author: Tahmina Afrose, Lecturer, FOM, Department of Community Medicine, AIMST University, Semeling, Bedong, Kedah, Malaysia, Email: drafrosekeya@gmail.com

\section{Demographic Trends and the Population Ageing: Why Matters?}

The Future of an economy is determined by the demographics characteristics. The demographic trends that we are facing in the world right now are:

1. The ratio of children to older citizens is declining: By 2050, there will be twice as many older citizens as there are children. "The number of over-60s in the rich world is predicted to rise by 2.5 times by 2050 to 418 million".

2. Rapid aging and rising longevity: This is due to improved health care services.

3. The burden of chronic and non-communicable diseases: Due to Increase life expectancy ratio.

4. Rapid rising in emerging economies: so that the emerging markets have less time to build the financial infrastructure and social security systems to deal with consequences of an aging and rising old age dependency.

5. Increasing old age dependency ratio: This is due to improvement in family planning and late marriage and increased longevity. Example is Germany, Japan, Italy, and Spain.

6. Rapid rising in global migration. : One key driver the hazards, both natural and manmade and the other biggest driver is opportunity and the third one important key factor is security. Usually people like to see the availability of better options for their children and families which cause them to move from middle-income nation to high-income nations.
7. The shift in the middle class with rapid growth in urbanization.

8. Decreasing fertility rate.

9. Older people in all countries are a vital resource to their families and the communities. Rapid ageing in both develop and the developing countries has shown the significant changes in the following aspects:

10. In the family structures.

11. In labor patterns.

12. In migration.

13. Pensions will need to cover a longer period of life.

14. Health care costs [1].

Due to involvement of more women in formal workforce, fewer people are available to take care of the older people. Increase in the global average life expectancy, decreasing the fertility rates and the overall improvement of the medical care services are the key issues for the rapid population aging. As we enter the process of globalization, ageing will put increased economic and social demands on both in developing and the developed countries [2].

\section{References}

1. Why Population Aging Matters Global Perspective (2007) National Institute on Aging National Institute of Health, US Department of Health and Human Services, USA, p. 6-7.

2. World Population Ageing: 1950-2050 (2002) United Nations Population Division (UNPD), USA, p. 11. 
This work is licensed under Creative Commons Attribution 4.0 Licens DOI: 10.19080/JOJPH.2017.01.555568

\section{Your next submission with Juniper Publishers will reach you the below assets}

- Quality Editorial service

- Swift Peer Review

- Reprints availability

- E-prints Service

- Manuscript Podcast for convenient understanding

- Global attainment for your research

- Manuscript accessibility in different formats

( Pdf, E-pub, Full Text, Audio)

- Unceasing customer service

Track the below URL for one-step submission https://juniperpublishers.com/online-submission.php 